\title{
KERAGAMAN TRUSS MORFOMETRI IKAN NILA (Oreochromis niloticus) STRAIN 69, GIFT G-3, DAN GIFT G-6
}

\author{
Didik Ariyanto dan Imron
}

\begin{abstract}
ABSTRAK
Penelitian untuk mengidentifikasi keragaman morfologi 3 strain ikan nila (Oreochromis niloticus) telah dilakukan dengan menggunakan metode truss morfometri dan analisis multivariasi. Duapuluh satu jarak truss diukur dari 191 sampel ikan yang mewakili 3 strain yaitu nila 69 , nila GIFT (Genetic Improvement of Farmed Tilapia) G-3, dan nila GIFT G-6. Analisis ragam multivariasi dan analisis komponen utama (Principal Component Analysis/PCA) digunakan untuk mengeksplorasi pola-pola keragaman morfologi dari 3 strain tersebut. Penelitian ini dilakukan untuk mendapatkan data dasar keragaman genetik ikan nila melalui pendekatan morfologis dalam rangka pemuliaan dan pengembangan komoditas tersebut. Hasil analisis secara umum menunjukkan bahwa bentuk tubuh ikan nila 69 cenderung berbeda dengan nila GIFT, baik G-3 maupun G-6. Keragaman karakter-karakter truss morfometri antara kedua strain tersebut banyak disebabkan oleh keragaman karakter truss pada kepala, badan bagian belakang, dan batang ekor. Hasil analisis menempatkan ikan nila 69 dalam 1 kelompok, sedangkan ikan nila GIFT G3 dan G-6 dalam kelompok lainnya.
\end{abstract}

ABSTRACT: Analysis of truss morphometric variability of nile tilapia strain $69_{3}$ GIFT G-3, and GIFT G-6. By: Didik Ariyanto and Imron

This study aimed to identify morphological variability in 3 strains of nile tilapia (O. niloticus) by using truss morphometric and multivariate analysis methods. Twenty one truss characters were measured on 191 fishes representing 3 strains (tilapia 69, GIFT G-3, and GIFT G-6). Multivariate analysis of variance (Manova) and Pricipal Component Analysis (PCA) were applied to explore the morphological variability among the 3 strains. The result showed that body form of tilapia 69 differed from GIFT G-3 and G-6. Truss character at the head, body, and caudal peduncle contributed most to separation among strains. Based on those characters, two distinct groups were formed, where tilapia 69 in one group and both GIFT G-3 and G-6 were in another.

KEYWORDS: Variability, truss morphometric, nile tilapia

\section{PENDAHULUAN}

Untuk meningkatkan produksi ikan nila (Oreochromis niloticus) pada tahun 1994 pemerintah melalui Balai Penelitian Perikanan Air Tawar (Balitkanwar) mengintroduksi ikan nila unggul hasil seleksi yang dilakukan oleh ICLARM di Philipina yang disebut nila GIFT (Genetic Improvement of Farmed Tilapia) generasi ke-3 (G-3). Ikan nila GIFT adalah ikan hasil seleksi dan persilangan dari 8 strain ikan nila yang dikumpulkan dari 8 negara di dunia yaitu Mesir, Ghana, Senegal, Kenya, Israel, Singapura, Thailand, dan Taiwan (Velasco et al., 1996). Ikan nila GIFT G-3 ini melengkapi koleksi ikan nila yang sudah diintroduksikan pada tahun-tahun sebelumnya. Ikan nila tersebut adalah ikan nila 69 yang diintroduksikan tahun 1969, kemudian nila red NIFI diintroduksikan pada tahun 1981. Pada tahun 1984 pemerintah kembali mendatangkan ikan nila yang dikenal dengan nama black Chitralada. Pada tahun 1996 pemerintah mengintroduksi lagi ikan nila GIFT dari Philipina yaitu ikan nila GIFT generasi ke-6 (G-6). Karena ikan nila GIFT G-6 ini pertumbuhannya relatif lebih baik daripada ikan-ikan nila sebelumnya, termasuk ikan nila GIFT G-3, maka ikan ini cepat sekali berkembang dan menyebar di kalangan petani ikan.

Penyebaran ikan nila GIFT yang pesat akhir-akhir ini menyebabkan kualitasnya tidak terkontrol dan cenderung menurun. Hal ini diduga karena banyak terjadi silang dalam (inbreeding) di dalam usaha budi daya yang meliputi perbenihan dan pembesaran. Indikasi dari penurunan kualitas genetik ikan ini ditandai dengan sifat-sifat seperti pertumbuhan lambat, tingkat kematian tinggi, dan matang kelamin dini. Untuk mengatasi masalah ini perlu dilakukan perbaikan genetik ikan nila (Imron et al., 2000).

Sebagai langkah awal upaya perbaikan ini adalah dengan mengoleksi strain-strain ikan nila yang berkembang di masyarakat, yang diharapkan mempunyai sifat-sifat genetik unggul. Pemanfaatan keragaman genetik beberapa strain ikan nila untuk

Peneliti pada Balai Penelitian Perikanan Air Tawar, Sukamandi 
tujuan pemuliaan tersebut membutuhkan pengenalan mengenai karakter dari strain-strain ikan, termasuk di dalamnya karakter morfologi dari komoditas tersebut. Pengukuran karakter morfologi menggunakan pola truss network (Strauss \& Bookstein, 1982 dalam Imron et al., 2000) memberikan gambaran bentuk tubuh yang menyeluruh. Metode ini menghasilkan karakterisasi geometrik bentuk tubuh ikan secara lebih sistematik sehingga akan menunjukkan peningkatan kemampuan dalam mengidentifikasi perbedaanperbedaan bentuk tubuh ikan (Imron et al., 2000). Metode ini dipakai juga karena metode analisis morfologi tradisional yaitu perbandingan secara univariasi karakter meristik dan morfometrik seperti panjang tubuh, lebar tubuh, dan tinggi tubuh seringkali gagal mengidentifikasi perbedaan antar strain/ populasi. Metode tradisional tersebut hanya mampu mengidentifikasi perbedaan populasi antar spesies.

Metode analisis statistik multivariasi menggunakan data truss network dengan tujuan mengidentifikasi nila selanjutnya. Selain itu juga sebagai bahan referensi terhadap komoditas ikan nila yang menyebar di tingkat pengguna.

\section{BAHAN DAN METODE}

Tiga strain ikan nila yaitu nila 69 , nila GIFT G-3, dan nila GIFT G-6 digunakan sebagai sampel dalam penelitian ini. Sampel nila GIFT G-3 dan G-6 adalah koleksi hidup milik Balitkanwar, Sukamandi. Sedangkan sampel ikan nila 69 dikoleksi dari daerah Cianjur selatan yang terisolasi dari sebaran ikan nila GIFT yang sekarang ini sudah sangat meluas. Jumlah dan ukuran sampel disajikan dalam Tabel 1.

Untuk memudahkan pengukuran dan mendapatkan data yang lebih akurat, sebelum dilakukan pengukuran, ikan dibius dengan obat bius 2-penoksi etanol selama 3 menit. Setelah ikan setengah sadar, sampel diletakkan di atas kertas tahan air dengan kepala di sebelah kiri. Titik-titik patokan

Tabel 1. Jumlah dan bobot rata-rata ikan nila (O. niloticus) yang digunakan untuk pengukuran jarak truss morfometri

Table 1. The numbers and average body weight of nile tilapia (O. niloticus) used for truss morphometric measurement

\begin{tabular}{|c|c|c|c|c|c|c|}
\hline \multirow{2}{*}{$\begin{array}{l}\text { Strain } \\
\text { Strain }\end{array}$} & \multicolumn{2}{|c|}{ Jantan (Male) } & \multicolumn{2}{|c|}{ Betina (Female) } & \multicolumn{2}{|c|}{$\begin{array}{l}\text { Jantan dan betina } \\
\text { Male and female }\end{array}$} \\
\hline & $\begin{array}{c}\text { Jumlah } \\
\text { Total }\end{array}$ & $\begin{array}{c}\text { Bobot } \\
\text { Weight (g) }\end{array}$ & $\begin{array}{c}\text { Jumlah } \\
\text { Total }\end{array}$ & $\begin{array}{c}\text { Bobot } \\
\text { Weight (g) }\end{array}$ & $\begin{array}{c}\text { Jumlah } \\
\text { Total } \\
\end{array}$ & $\begin{array}{c}\text { Bobot } \\
\text { Weight (g) }\end{array}$ \\
\hline 69 & 21 & $\begin{array}{c}26.75 \\
(8.378)\end{array}$ & 29 & $\begin{array}{c}27.59 \\
(7.965)\end{array}$ & 50 & $\begin{array}{c}27.24 \\
(8.067)\end{array}$ \\
\hline GIFT G-3 & 18 & $\begin{array}{l}138.14 \\
(25.177)\end{array}$ & 23 & $\begin{array}{l}104.31 \\
(23.068)\end{array}$ & 41 & $\begin{array}{c}119.16 \\
(29.170)\end{array}$ \\
\hline GIFT G-6 & 42 & $\begin{array}{l}196.17 \\
(65.00)\end{array}$ & 58 & $\begin{array}{l}168.93 \\
(69.505) \\
\end{array}$ & 100 & $\begin{array}{c}180.8 \\
(67.238) \\
\end{array}$ \\
\hline $\begin{array}{c}\text { Jumlah } \\
\text { Total }\end{array}$ & 81 & & 110 & & 191 & \\
\hline
\end{tabular}

Nilai dalam kurung adalah standar deviasi (Values in bracket represent standard deviation)

stok-stok ikan telah banyak dilakukan, misalnya Edge et al. (1991) pada ikan whitefish, Coregenus sp.; Swain et al. (1991); serta Swain \& Holtby (1989) pada ikan salmon, Oncorhynchus kisutch. Metode serupa. juga telah dilakukan oleh Nugroho et al. (1991) dan Imron et al. (2000) pada ikan mas.

Penelitian ini bertujuan untuk mengidentifikasi keragaman genetik 3 strain ikan nila yaitu strain 69 , GIFT G-3, dan GIFT G-6 melalui pendekatan morfologi dengan menggunakan data truss morfometri dan analisis statistik multivariasi. Hasil dari penelitian ini adalah berupa data dasar untuk digunakan dalam rangka pemuliaan dan pengembangan komoditas ikan yang jelas, konsisten, dan homolog dari satu sampel ke sampel yang lain ditentukan di sekitar garis bentuk tubuh ikan (Imron et al., 2000). Sepuluh buah titik patokan yang ditentukan (Gambar 1) membagi bentuk tubuh ikan menjadi 4 bagian dan menghasilkan 21 karakter truss (Tabel 2). Setiap titik patokan ditandai dengan menggunakan sebatang jarum yang ditusukkan ke kertas tahan air yang berada di bawah sampel. Untuk memudahkan pelubangan, dibawah kertas tersebut diletakkan sehelai stereofoam setebal 1 inci. Pengukuran jarak antara titik-titik patokan tersebut yang terdiri atas 4 garis sisi dan 2 garis di- 


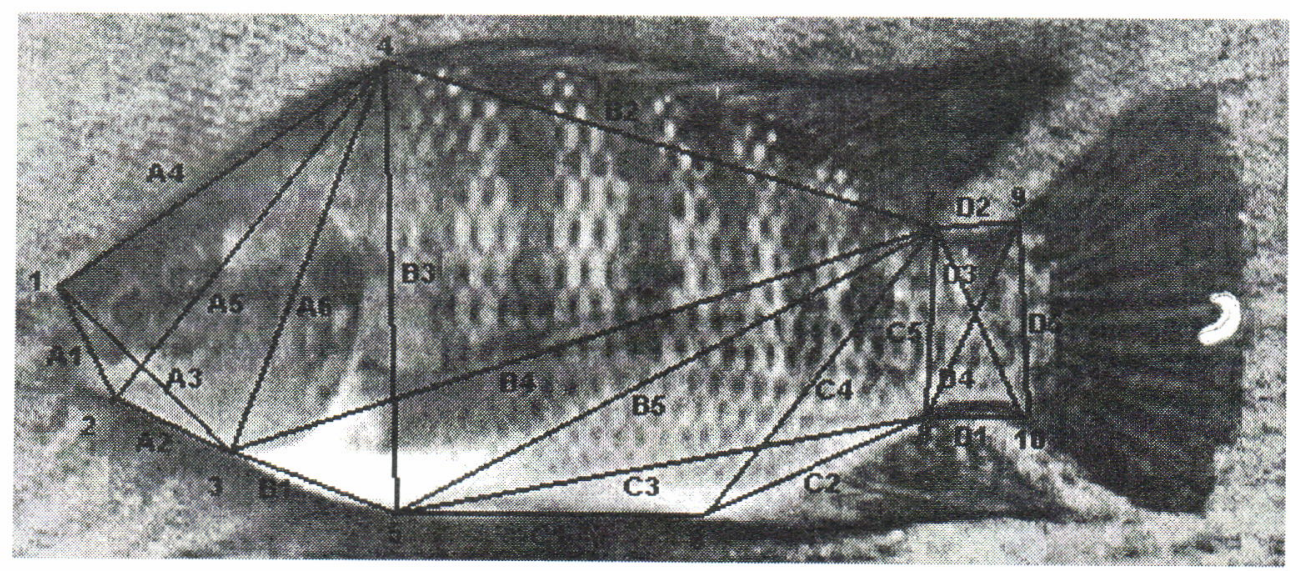

Gambar 1. Lokasi 10 titik yang ditentukan di garis luar tubuh ikan untuk mendapatkan data truss mofometri. Titik-titik landmark merujuk kepada (1) mulut atas, (2) titik posterior maksila, (3) is'thmus, (4) pangkal sirip punggung, (5) pangkal sirip perut, (6) pangkal sirip anus, (7) ujung sirip punggung, (8) ujung sirip anus, (9) pangkal atas sirip ekor, (10) pangkal bawah sirip ekor. Penjelasan untuk kombinasi huruf dan angka dapat dilihat pada Tabel 2

Figure 1. Location of 10 landmark point on the body outline for gathering truss network data. Landmark points refer to (1) anterior tip of snout at upper jaw, (2) posterior point of maxillary, (3) is'thmus, (4) origin of dorsal fin, (5) origin of pelvic fin, (6) origin of anal fin, (7) insertion of dorsal fin, (8) insertion of anal fin, (9) origin of upper caudal fin, (10) origin of lower caudal fin. Complete explanation for combined letter and number, see as in Table 2

agonal pada setiap bidang, dilakukan dengan menggunakan mistar dengan ketelitian $0,5 \mathrm{~mm}$.

Identifikasi keragaman bentuk antar strain harus bebas dari bias yang disebabkan oleh perbedaan ukuran (Imron et al., 2000). Perbedaan ukuran yang ada pada ketiga sampel tersebut diharapkan tidak menimbulkan bias. Upaya untuk meminimalkan pengaruh keragaman ukuran adalah dengan mengikuti prosedur Edge et al. (1991). Seluruh data morfometri ditransformasikan ke logaritma natural dan distandardisasi ke rata-rata $=0$ dan simpangan baku $=1$. Karakter morfometri kemudian ditransformasi menjadi peubah-peubah bentuk berupa sisaan yang merupakan selisih antara nilai-nilai karakter individu terhadap garis regresi dalam seluruh kelompok yang menggambarkan hubungan antara karakter yang bersangkutan dengan panjang standar. Sisaan yang bebas dari pengaruh ukuran, selanjutnya digunakan sebagai karakter morfometri untuk analisis multivariasi.

Analisis ragam multivariasi (manova) digunakan sebagai analisis pendahuluan untuk mengetahui kemungkinan adanya fenomena seksual dimorfisme. Untuk tujuan ini masing-masing strain dianalisis secara terpisah antara populasi jantan dan betina. Jika nilai rata-rata vektor antara jantan dan betina tidak menunjukkan perbedaan $(P>0,05)$ maka analisis komponen utama (Principal Component Analysis) yang bertujuan untuk mengidentifikasi pola-pola keragaman antar strain (Strauss \& Bond, 1990) dilakukan dengan menggunakan data gabungan antara jantan dan betina. Sebaliknya apabila nilai rata-rata vektor antara jantan dan betina menunjukkan perbedaan $(P<0,05)$ pada sembarang strain, maka analisis PCA menggunakan data yang terpisah antara jantan dan betina. Analisis menggunakan data gabungan dilakukan sebagai pembanding (Velasco et al., 1996). Analisis manova dan PCA dilakukan dengan program Statistical Package for Social Science (SPSS)

\section{HASIL DAN BAHASAN}

Hasil analisis multivariasi (manova) yang disajikan dalam Tabel 3 menunjukkan bahwa fenomena seksual dimorfisme berdasarkan truss pada ikan nila tidak terlihat nyata. Hal ini ditunjukkan oleh nilai $p$ lebih besar daripada 0,05. Menurut Strauss \& Bond (1990) dan Velasco et al. (1996), jika hasil analisis nilai $\mathrm{P}>0,05$ maka fenomena seksual dimorfisme pada suatu populasi ikan tidak nyata, sehingga analisis untuk pembandingan bentuk tubuh antar populasi dilakukan dengan data gabungan antara populasi jantan dan betina.

Fenomena seksual dimoriisme pada ikan nila akan muncul pada ikan yang berukuran lebih atau sama dengan $200 \mathrm{~g}$ per ekor, sedangkan sampel ikan dalam penelitian ini berukuran kurang dari $200 \mathrm{~g}$ per ekor, sehingga fenomena tersebut belum terlihat nyata.

Berdasarkan hasil analisis multivariasi di atas, maka analisis komponen utama yang bertujuan untuk membandingkan bentuk tubuh antar strain dilakukan dengan menggunakan data gabungan antara jantan dan betina. Hasil analisis komponen utama 
Tabel 2. Deskripsi 21 karakter truss morfometri yang diukur untuk analisis variabilitas intraspesifik Table 2. Description of 21 truss morphometric characters measured for intraspecific variability analysis

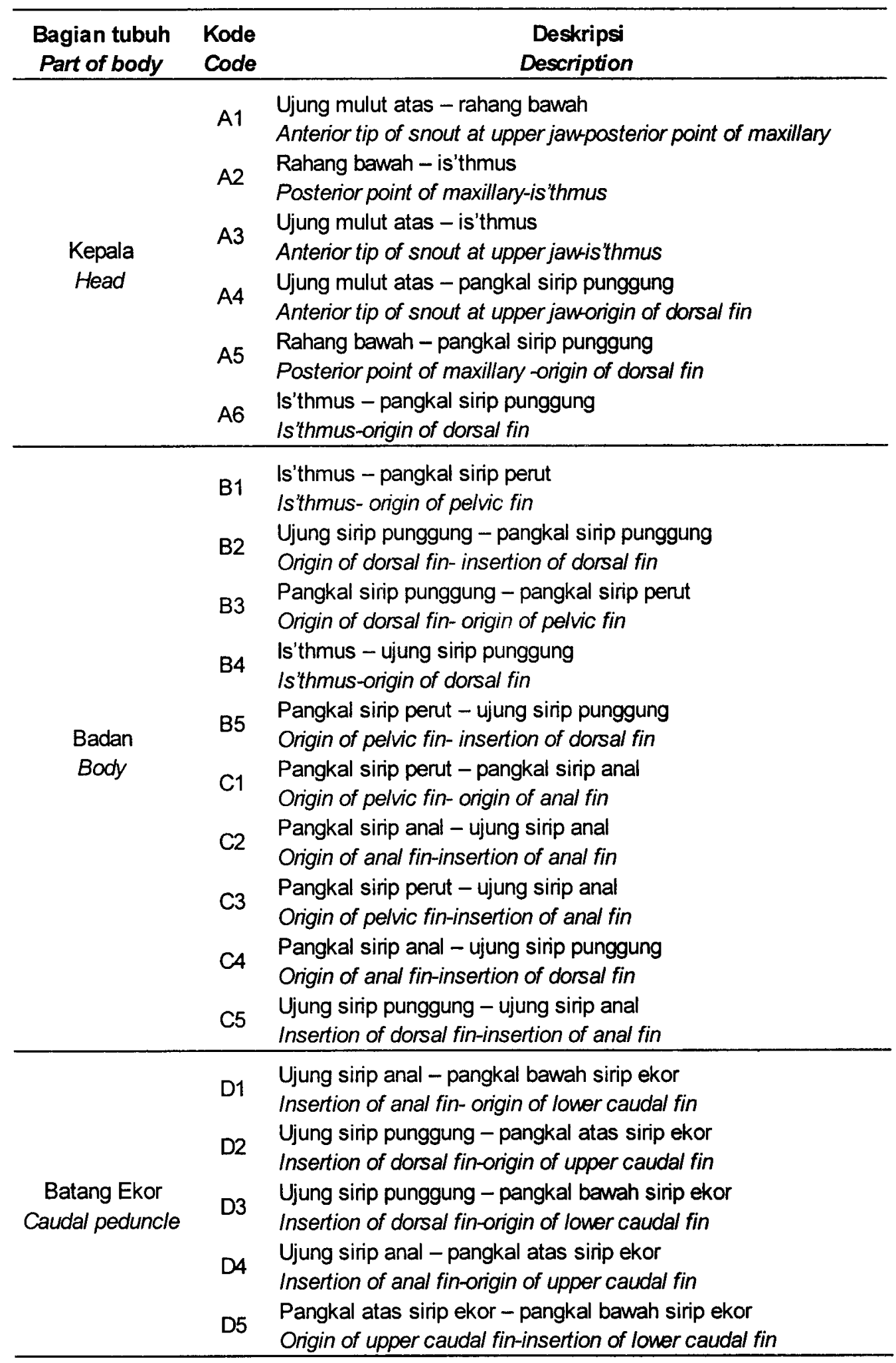

dan betina. Hasil analisis komponen utama menggunakan 21 karakter truss morfometri dari ketiga strain ikan nila tersebut disajikan dalam Tabel 4.
Berdasarkan hasil analisis yang dilakukan (Tabel 4), terlihat bahwa proporsi keragaman komponen utama 1 sebesar $21,041 \%$. Hasil ini menunjukkan 
Tabel 3. Hasil analisis ragam multivariasi (manova), nilai p yang menguji pengaruh perbedaan sex terhadap bentuk tubuh pada 3 strain ikan nila

Table 3. Results of multivariate variance analysis (manova), $p$ values examining effect of sex differences on body shape in 3 strains of nile tilapia

\begin{tabular}{lc}
\multicolumn{1}{c}{ Strain } & P \\
\hline Nila 69 & 0.487 \\
Nila GIFT G-3 & 0.412 \\
Nila GIFT G-6 & 0.422 \\
\hline
\end{tabular}

Tabel 4. Skor dan proporsi keragaman yang dapat dijelaskan oleh empat sumbu utama pertama pada analisis komponen utama menggunakan 21 karakter truss morfometri pada 3 strain ikan nila

Table 4. Scores and explained variabilities by first four PCs in Principal Component Analysis (PCA) using 21 truss morphometric characters in 3 strains of nile tilapia

\begin{tabular}{|c|c|c|c|c|}
\hline \multirow{2}{*}{$\begin{array}{l}\text { Karakter truss } \\
\text { Truss characters }\end{array}$} & \multicolumn{4}{|c|}{$\begin{array}{l}\text { Nilai komponen utama } \\
\text { Main component care }\end{array}$} \\
\hline & PC1 & PC 2 & PC 3 & $\mathrm{PC} 4$ \\
\hline \multicolumn{5}{|l|}{ 1. Kepala (Head) } \\
\hline A1 & 0.095 & -0.146 & 0.054 & 0.178 \\
\hline A2 & 0.113 & -0.121 & -0.011 & 0.292 \\
\hline A3 & 0.097 & -0.216 & -0.057 & 0.230 \\
\hline A4 & 0.074 & -0.218 & -0.098 & -0.232 \\
\hline A5 & 0.142 & -0.138 & -0.202 & -0.049 \\
\hline A6 & 0.160 & -0.066 & -0.211 & -0.109 \\
\hline \multicolumn{5}{|l|}{ 2. Badan (Body) } \\
\hline $\mathrm{B1}$ & 0.079 & 0.146 & 0.059 & -0.199 \\
\hline B2 & 0.047 & 0.227 & -0.092 & 0.108 \\
\hline B3 & 0.171 & 0.059 & -0.165 & -0.023 \\
\hline B4 & 0.088 & 0.271 & -0.027 & -0.058 \\
\hline B5 & 0.051 & 0.004 & 0.068 & 0.273 \\
\hline $\mathrm{C} 1$ & 0.056 & 0.168 & -0.042 & 0.299 \\
\hline $\mathrm{C} 2$ & 0.116 & -0.026 & 0.131 & 0.033 \\
\hline C3 & 0.077 & 0.170 & -0.072 & 0.236 \\
\hline $\mathrm{C} 4$ & 0.172 & 0.045 & 0.073 & -0.090 \\
\hline C5 & 0.145 & 0.055 & 0.073 & -0.134 \\
\hline \multicolumn{5}{|c|}{ 3. Batang Ekor (Caudal peduncle) } \\
\hline D1 & 0.045 & -0.060 & 0.308 & 0.052 \\
\hline D2 & 0.036 & -0.077 & 0.310 & 0.041 \\
\hline D3 & 0.105 & 0.021 & 0.227 & -0.162 \\
\hline D4 & 0.071 & 0.060 & 0.206 & 0.012 \\
\hline D5 & 0.121 & 0.018 & 0.036 & -0.133 \\
\hline $\begin{array}{l}\text { Proporsi keragaman (\%) } \\
\text { Variability proportion (\%) }\end{array}$ & 21.041 & 13.690 & 11.903 & 7.906 \\
\hline $\begin{array}{l}\text { Keragaman kumulatif (\%) } \\
\text { Cumulative variability (\%) }\end{array}$ & 21.041 & 34.730 & 46.634 & 54.540 \\
\hline
\end{tabular}

Angka-angka yang dicetak tebal menggambarkan skor yang dianggap signifikan, di mana nilai absolutnya lebih dari setengah nilai koefisien maksimal pada PC yang bersangkutan (Velasco et al., 1996)

- Bold printer figures represent score considered to be significant which absolute value is greater than half maximum coefficient for relevant PC (Velasco et al., 1996) 
bahwa karakter-karakter tersebut hanya sedikit memberikan kontribusi dalam membedakan bentuk tubuh antar strain pada ikan nila. Namun demikian proporsi keragaman kumulatif sampai dengan komponen utama 4 sebesar $54,540 \%$ mengindikasikan bahwa karakter-karakter tersebut di atas memberikan kontribusi yang cukup kuat dalam membedakan bentuk tubuh pada ikan nila. Hal ini berarti karakter-karakter truss pada penelitian ini sudah cukup untuk mengidentifikasi pola-pola keragaman bentuk tubuh antar strain pada ikan nila.

Berdasarkan nilai-nilai komponen utama pada Tabel 4, keragaman bentuk antar strain pada ikan nila banyak disebabkan oleh variasi bentuk kepala, badan, besar dalam membedakan bentuk tubuh antar strain pada ikan nila adalah D1, D2, D3, D4, dan D5 yang terdapat pada komponen 1 dan 3.

Diagram pencar skor individu-individu pada komponen utama 1 dan 3 (Gambar 2) memperlihatkan adanya pola pengelompokan antar strain, di mana $92 \%$ dari sampel ikan nila 69 yang digunakan mengelompok pada sumbu negatif komponen 3 . Karakter-karakter truss yang dominan membentuk sumbu komponen 3 adalah D1, D2, D3, dan D4.

Diagram pencar skor individu-individu pada komponen utama 2 dan 3 (Gambar 3 ) memperlihatkan adanya pola pengelompokan antar strain, di mana 95 $\%$ dari sampel ikan nila 69 yang digunakan

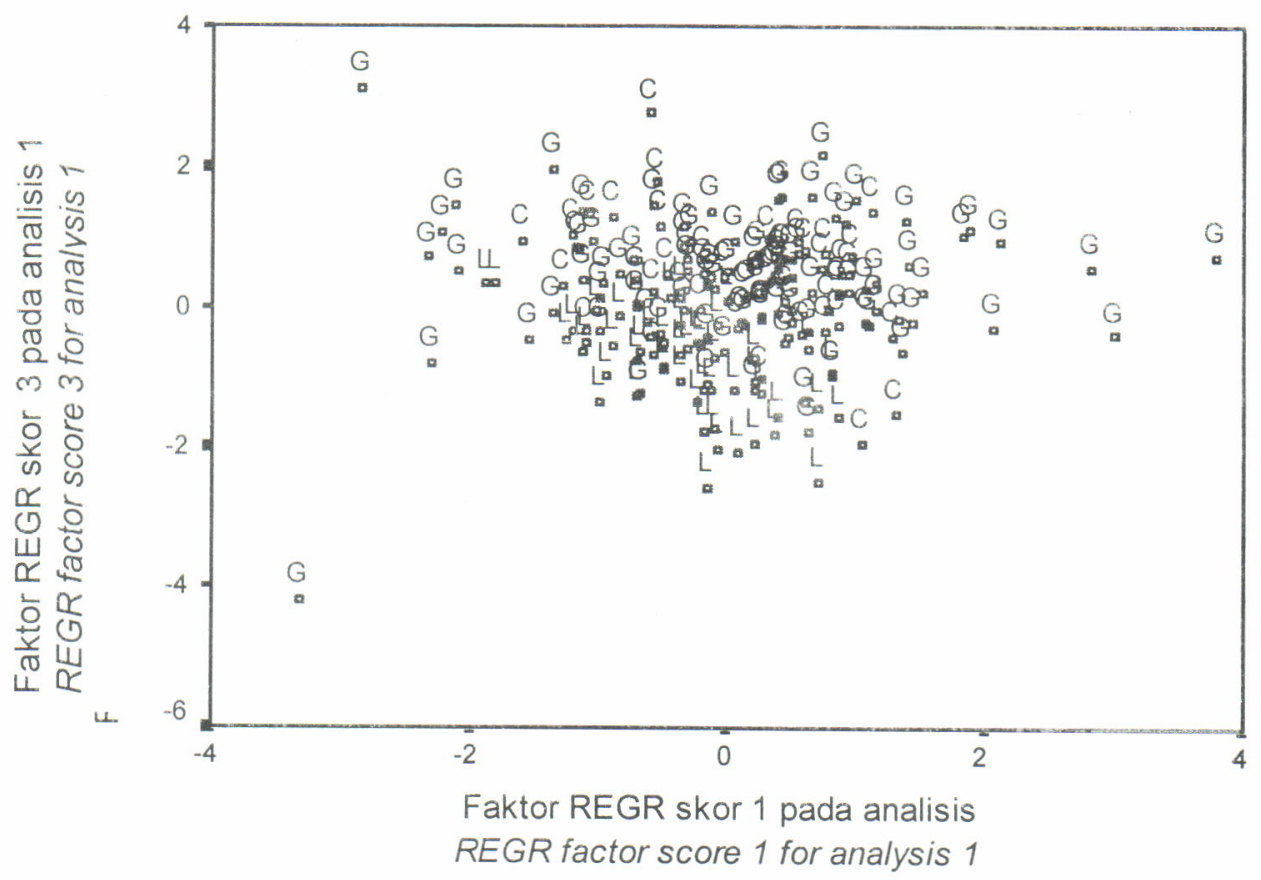

\section{Keterangan (Remaks): L : Nila $69 \quad$ C : Nila GIFT G-3 $\quad$ G : Nila GIFT G-6}

Gambar 2. Diagram pencar skor komponen utama sepanjang komponen utama 1 dan 3 menggunakan 21 karakter truss morfometri

Figure 2. Scater plot of Principal Componen (PC) scores along the first and third component using 21 truss morphometric characters

dan batang ekor. Lima dari 6 karakter truss pada bagian kepala yaitu $A 1, A 2, A 3, A 5$, dan $A 6$ mempunyai nilai-nilai yang relatif besar pada komponen utama 1 dan 4. Pada bagian badan komponen-komponen yang mempunyai nilai cukup besar relatif banyak dan menyebar pada komponen 1, 2, 3, dan 4. Pada bagian ini karakter truss yang memberikan kontribusi cukup besar dalam membedakan bentuk tubuh ikan nila adalah B1, B2, B4, C1, C3 (komponen 2); B3, B4, C2, C4, C5 (komponen 1); C2 (komponen 3); dan B5, C1, C3 (komponen 4). Sedangkan pada bagian batang ekor, karakter truss yang juga memberikan kontribusi cukup mengelompok pada sumbu negatif komponen 3 . Karakter-karakter truss yang dominan membentuk sumbu komponen 3 adalah D1, D2, D3, dan D4. Sedangkan jika dilihat dari komponen 2, pola pengelompokan antar strain yang berbeda tidak terlihat.

Diagram pencar skor individu-individu pada komponen utama 3 dan 4 (Gambar 4) memperlihatkan adanya pola pengelompokan antar strain, di mana 87 $\%$ dari sampel ikan nila 69 yang digunakan mengelompok pada sumbu negatif komponen 3 . Karakter-karakter truss yang dominan membentuk sumbu komponen 3 adalah D1, D2, D3, dan D4. Jika 


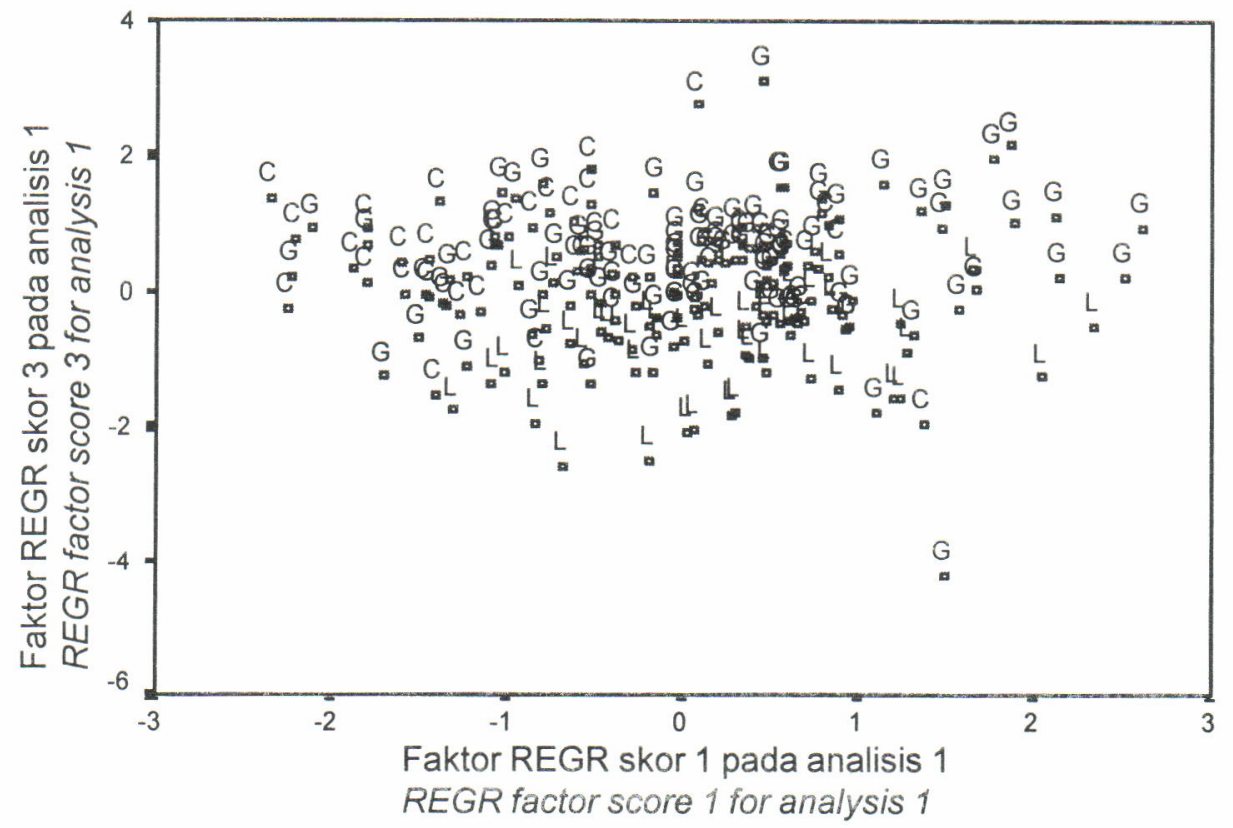

Keterangan (Remarks): L : Nila $69 \quad$ C : Nila GIFT G-3 G : Nila GIFT G-6

Gambar 3. Diagram pencar nilai komponen utama sepanjang komponen utama 2 dan 3 menggunakan 21 karakter truss morfometri

Figure 3. Scater plot of Principal Component (PC) scores along the second and third component using 21 truss morphometric characters

dilihat dari komponen 4, terlihat bahwa $75 \%$ dari sam- karakter yang membedakan ikan nila 69 dari nila GIFT pel ikan nila 69 berada pada sumbu positif. Karakter- pada komponen ini adalah A1, A2, A3, B5, C1, dan C3.

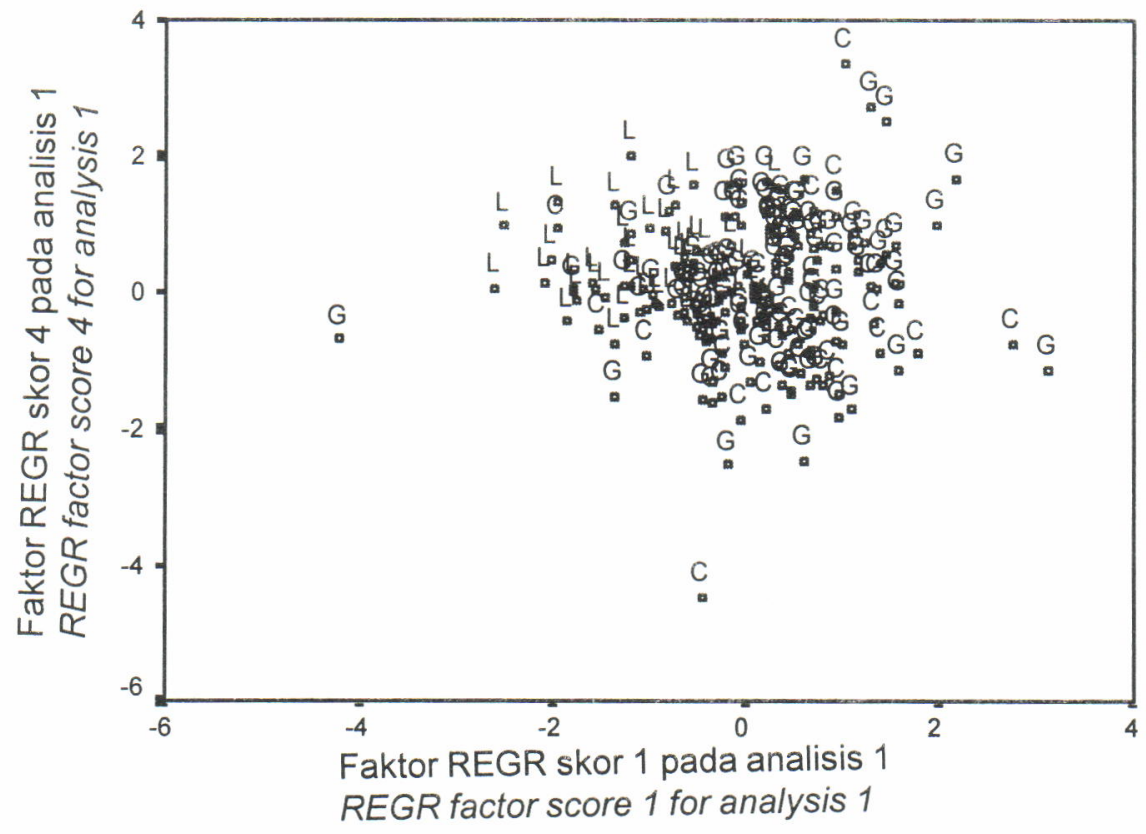

Keterangan (Remarks): L : Nila 69 C : Nila GIFT G-3 G : Nila GIFT G-6

Gambar 4. Diagram pencar skor komponen utama sepanjang komponen utama 1 dan 4 menggunakan 21 karakter truss morfometri

Figure 4. Scater plot of Principal Component (PC) scores along the first and fourth component using 21 truss morphometric characters 


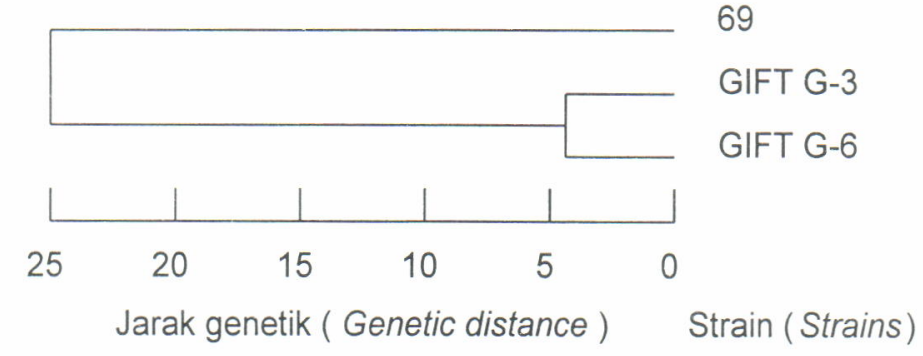

Gambar 5. Dendrogram yang menggambarkan jarak genetik ketiga strain ikan nila berdasarkan bentuk tubuh menggunakan 21 karakter truss morfometri

Figure 5. Dendrogram represent the genetic distance among 3 strains of nile tilapia using 21 truss morphometric characters

Dari ketiga diagram pencar tersebut tidak terlihat pengelompokan antar strain pada nila GIFT G-3 dan GIFT G-6. Ketidakjelasan pengelompokan nila GIFT G-3 dan GIFT G-6 menunjukkan bahwa secara morfologis kedua strain ini mempunyai kemiripan yang tinggi dan diduga secara genetik masih mempunyai hubungan kekerabatan yang dekat. Hal ini sangat dimungkinkan karena kedua strain ikan nila ini didapatkan dari hasil seleksi dan upaya pemuliaan yang sama. Sedangkan ikan nila 69 yang terlihat mengelompok tersendiri diduga karena ikan nila 69 mempunyai hubungan kekerabatan yang jauh dari ikan nila GIFT. Hal ini sesuai dengan asal-usul ketika ikan tersebut diintroduksikan ke Indonesia

Karakter-karakter truss yang dominan membedakan bentuk tubuh ikan nila 69 dengan nila GIFT secara jelas adalah bagian kepala yang terdiri atas bidang $A 1, A 2$, dan $A 3$; bagian badan yang terdiri atas bidang B5, C1, dan C3. Sedangkan bagian batang ekor yang dominan adalah bidang D1, D2, D3, dan D4.

Dalam bentuk dendrogram (Gambar 5), hubungan ketiga strain ikan nila digambarkan sebagai berikut. Nila GIFT G-3 dan GIFT G-6 menjadi 1 kelompok karena jarak hubungan kekerabatan yang dekat, tetapi keduanya sama-sama mempunyai hubungan kekerabatan yang jauh dengan nila 69. Hal ini sesuai dengan nilai-nilai komponen utama pada analisis PCA maupun ketiga diagram pencar di atas.

\section{KESIMPULAN}

Berdasarkan hasil-hasil pengukuran karakterkarakter truss morfometri, keragaman morfologi pada ikan nila lebih disebabkan oleh adanya perbedaan strain dan bukan karena perbedaan jenis kelamin. Keragaman morfologi antar strain terutama disebabkan oleh karakter-karakter truss pada bagian kepala, badan bagian belakang, dan batang ekor. Karakterkarakter truss pada bagian tersebut mengelompokkan nila strain 69 pada 1 kelompok sedangkan nila GIFT G-3 dan G-6 pada kelompok lainnya.

\section{DAFTAR PUSTAKA}

Edge, T.A., D.E. McAllister, and S.U. Qadri. 1991. Meristic and Morphometric Variation between The Endangered Acadian Whitefish, Coregonus hutsmani and The Lake Whitefish, Coregonus clupeaformis, in the Canadian Maritim Provinces and the State of Maine USA. Can. J. Fish Aquat. Sci. 48(11): 2.140--2.151.

Imron, O.Z. Arifin, dan Subagyo. 2000. Karakterisasi Truss Morfometrik pada Ikan Mas (Cyprinus carpio) Galur Majalaya, Rajadanu Wildan, dan Sutisna. Prosiding Seminar Hasil Penelitian Perikanan 1999/ 2000. Puslitbang Eksplorasi Laut dan Perikanan. Departemen Eksplorasi Laut dan Perikanan, Jakarta.

Nugroho, E., N.A. Wahyudi, dan Sudarto. 1991. Penentuan jenis kelamin ikan mas dengan membandingkan bentuk tubuh melalui teknik "truss morfometric". Buletin Penelitian Perikanan Darat 10(1): 23--29.

Strauss, R.E. and C.E. Bond. 1990. Taxonomic methods: morphology. In Shreck, C.B. and Moyle, C.B. (Eds). Methods for Fish Biology. American fisheries society, Bethesda, Maryland, USA. p. 109--140.

Swain, D.P. and L.B. Holtby. 1989. Differences in morphology and behavior between juvenile coho salmon, Oncorhynchus kisutch rearing in a lake or in its tributary stream. Can. J. Fish. Aquat. Sci. 46(8): 1.406-1.414

Swain, D.P., B.E. Riddell, and C.B. Murray. 1991. Morphological differences between hatchery and wild populations of coho salmon, Oncorhynchus kisutch: environmental versus genetic origin. Can. J. Fish. Aquat. Sci. 48(9): 1.783--1.791.

Velasco R.R., M.J.R. Pante, J.M. Macaranas, C.C. Janagap, and A.E. Eknath. 1996. Truss morphometric characterization of eight strains of Nile Tilapia $(O$. niloticus). 415--425 In. R.S.V. Pullin, J. Lazard, M. Legendre, J.B. Amon Kothias and D. Pauly (Eds.). The Third International Symposium on Tilapia in Aquaculture. ICLARM Conf. Proc. 4: 575 pp. 